dan niet gerechtvaardigd zijn van ontslag. Een klacht uit die tijd was wel dat geschoolde vrouwen vaak doorstroomden naar de politiek, zodat de bond voortdurend gebrek aan kader had.

In de jaren zeventig ging de Vrouwenbond mee in de stroom van maatschappijvernieuwing, zij het dat de oudere leden daar zeer gemengd over dachten. De enige actie die echt breed werd gedragen, was de door Man-Vrouw-Maatschappij gelanceerde 'Marie, wordt wijzer' - maar deze werd door vrijwel elke vrouwenorganisatie omarmd. Het is misschien te veel gevraagd om dit in een jubileumboek te beklemtonen, maar ondanks het feit dat de Vrouwenbond in deze periode zijn grootste ledental kende, 17.000, en zichzelf graag als initiatiefnemer zag, lijkt de bond mij meer door de stroom meegesleept dan gangmaker.

In 1981 werd de Vrouwenbond een bond met stemrecht in de FNV. In deze periode, waarin de vakbeweging zich met alle terreinen van het maatschappelijk leven ging bezighouden, vormde de Vrouwenbond de schakel tussen vrouwen- en vakbeweging.

Een sterk punt van het boek vormen de korte vignetten van voorzitters en sleutelfunctionarissen. Ze blijken vaak een enorme invloed te hebben; na vertrek slaat de bond vaak een heel andere richting in of krijgt zelfs een ander karakter.

Een zwak punt is het 'Tot besluit'. De toon wordt opeens een stuk onzakelijker, verzuchtingen en bewieroking wisselen elkaar af. Een voorbeeld: vakbonden 'zijn verenigingen die nog steeds zijn gedomineerd door mannen en die zich nog steeds voornamelijk toeleggen op belangenbehartiging van betaald werkenden' (140). Maar, zo vraagt de lezer zich bij het tweede deel van deze verzuchting af, waren vakbonden dan niet juist daarvoor opgericht?

Dit neemt niet weg dat we hier met een grondige studie te maken hebben, die op tal van archivalia, geschriften en interviews is gebaseerd en ook is voorzien van een notenapparaat en een literatuurlijst (geen index). Zowel de liefhebber van vakbonds- als van vrouwengeschiedenis zal hier veel van zijn gading vinden.

W. Pelt

J. Pekelder, Nederland en de DDR. Beeldvorming en betrekkingen 1949-1989 (Dissertatie Utrecht 1998; Amsterdam: Boom, 1998, 519 blz., f59,50, ISBN 905352387 1).

Op het brede onderzoeksveld van de beeldvorming van de DDR in Nederland en van de betrekkingen tussen Nederland en de DDR heeft de jonge Utrechtse historicus Pekelder (jaargang 1967) op een verstandige wijze paaltjes geslagen om in de buitengewoon overvloedige documentatie en literatuur het spoor niet bijster te raken. Na de liquidatie van de DDR in 1990 werden de barrières tot Oost-Duitse archieven snel afgebroken, waardoor veel nieuw archiefmateriaal beschikbaar kwam; ook bleek de toegang tot archieven in Nederland ineens een stuk gemakkelijker geworden te zijn. Dat noopte tot origineel onderzoek op tal van gebieden. Omdat het hier om een binnen een beperkte hoeveelheid tijd te voltooien proefschrift ging, was volledige dekking van het onderzoeksveld uitgesloten. Pekelder liet daarom interessante onderwerpen als de sportieve, culturele en wetenschappelijke contacten buiten beschouwing en concentreerde zich op de politieke, economische en kerkelijke banden en op de invloed van de beeldvorming op hun ontwikkeling. Daarmee is toch nog een reusachtig terrein van onderzoek afgepaald, waarop Pekelder zich inventariserend en analyserend heel bekwaam heeft bewogen.

Wat betreft de officiële betrekkingen is het verhaal snel verteld. De opeenvolgende Nederlandse regeringen hebben hun houding tegenover de DDR altijd consequent en braaf bepaald in het kader van het Atlantisch bondgenootschap en zich nooit van de wijs laten brengen door pressie 
van buiten af, die niet zelden vanuit de DDR werd geregisseerd en rond 1970 politiek een factor van enig gewicht was. Conform de bondgenootschappelijke afspraken legde de Nederlandse overheid zich in 1949 vast op een politiek van niet-erkenning en wachtte de eindjaren zestig onder de regering van Willy Brandt op gang gekomen ontwikkelingen in de DuitsDuitse betrekkingen af om, opnieuw conform bondgenootschappelijke afspraken, begin 1973 over te gaan tot erkenning van de DDR, nadat het basisverdrag tussen de Bondsrepubliek en de DDR was getekend. Na de normalisering van de betrekkingen stelde de Nederlandse regering zich evenwel tamelijk terughoudend op. Voor haar bleef de DDR 'een kunstmatige constructie met een ongelegitimeerd regime, waarmee zij zich zo min mogelijk geassocieerd wenste te worden', zo luidt de heldere conclusie van Pekelder (405).

Spannender en ook waardevoller is het boek als Pekelder de betrekkingen op andere niveaus beschrijft en analyseert. Dat geldt met name voor het in den brede behandelde erkenningsdebat, dat in de jaren zestig in en tussen politieke en maatschappelijke groeperingen werd gevoerd, een debat dat op de erkenning zelf overigens geen invloed heeft uitgeoefend. In grote lijnen is dat debat wel bekend, maar op basis van zijn archiefonderzoek brengt Pekelder heel wat nieuwe en tot nu toe onderbelichte aspecten in kaart en trekt hij stevige, maar tegelijkertijd overtuigende conclusies.

In de jaren vijftig was de DDR in Nederland een onbekend land. Het beeld was eenduidig: de DDR, lopend aan de leiband van Moskou, was een door en door stalinistisch land. De psychose van de Koude Oorlog en de vastbeslotenheid van de niet-erkenningspolitiek van de regering prikkelden de DDR-watchers - diplomaten en journalisten - allesbehalve tot kritische bezinning; integendeel, zij droegen veel cement aan om dit beeld vast te metselen. Halverwege de jaren zestig echter werd de DDR 'herondekt'. Het 'kleine Wirtschaftswunder' achter de Muur maakte nieuwsgierig. Nieuwe visies op de DDR kregen daardoor een kans. Voor bepaalde groeperingen en personen ging de DDR zelfs functioneren als een 'socialistische modelstaat'. Dat gebeurde het eerst in linkse protestantse kringen, waar men nu zinvolle mogelijkheden voor een dialoog tussen christenen en communisten aanwezig achtte. Iets later brak een DDReuforie door in de PSP en onder PvdA-jongeren die zich als Nieuw Links manifesteerden. De CPN is een verhaal apart; de moeizame relatie met Moskou plaatste de DDR zo goed als geheel uit haar blikveld.

Met kracht van argumenten, ontleend aan het Oost-Duitse archiefmateriaal, betoogt Pekelder dat de DDR-euforie in politiek links Nederland stoelde op een behoorlijke dosis naïviteit. DDR-instanties bleken niet veel moeite te hoeven doen om PSP en Nieuw Links voor hun erkenningskarretje te spannen; bezoekers aan de DDR bezweken snel en gemakkelijk voor de propaganda. Fries de Vries (PSP) en Han Lammers (Nieuw Links) spanden in dit opzicht de kroon. Met de bronnen in de hand rekent Pekelder genadeloos af met de positieve beelden, die zij van de DDR in omloop brachten; Lammers bijvoorbeeld trachtte de DDR zelfs te slijten als een andere vorm van democratie. Naïviteit bleef sommigen van deze generatie aankleven, ook toen zij op het pluche van de partijzetels terecht waren gekomen. In 1975 bracht een delegatie van het PvdA-bestuur een bezoek aan de DDR en raakte kennelijk zo in de ban van de gastheer dat na terugkeer de Muur een historische noodzaak en de erkenning van de DDR door Nederland veel te laat werden genoemd. Pekelder heeft er geen goed woord voor over. De uitspraken wekten trouwens ook in 1975 meteen een storm van verontwaardiging, ook binnen de PvdA. Het tij was zich toen al tegen de DDR aan het keren. De wijze waarop linkse regimecritici in de DDR het zwijgen kregen opgelegd en de snel groeiende aandacht in Nederland voor de mensenrechten begonnen het prestige, dat de DDR in progressieve kringen had verworven, danig te schaden. Het aantal Nederlanders dat de DDR beschouwde als een voorpost van de ideale socialistische staat, daalde vanaf de jaren zeventig gestaag. 
Kennelijk heeft Pekelder zich er erg over verbaasd dat later vooraanstaande politici als Han Lammers in hun vormingsjaren zoveel onnozelheid aan de dag hebben gelegd. Maar verbazing heeft geen historische verklaringskracht. Pekelder laat het er dan ook daar niet bij. Hij plaatst die onnozelheid in het bredere kader van de 'revolutie' van de jaren zestig om te laten zien dat er met de omarming van de DDR heel wat meer aan de hand was dan alleen maar blinde liefde. Zo speelde angst voor een herleving van het Duitse gevaar een rol en beschouwde men de DDR als de beste garantie daartegen. Naast uitlaatklep voor anti-Duitse gevoelens was het erkenningsdebat zeker voor Nieuw Linksers ook een middel om hun overtuiging kracht bij te zetten dat de oriëntatie van de buitenlandse politiek zich diende te verschuiven van confrontatie jegens het Sovjetblok naar ontspanning. Maar bovenal vervulde het ijveren voor de erkenning van de DDR binnen Nieuw Links een strategische functie; door aan de houding ten opzichte van de DDR de partijleden de maat van progressiviteit te nemen dachten de Nieuw Linksers de oudere bestuurders in een in de ogen van de jongeren ongunstig licht te kunnen stellen om vervolgens zelfde bestuurszetels te claimen omdat alleen zij borg stonden voor de noodzakelijke vernieuwing. Deze strategie heeft gewerkt, maar zoals gezegd heeft het erkenningsdebat op het niveau van de hogere politiek geen uitwerking gehad: de PvdA-fractie in de Tweede Kamer volgde de regeringslijn.

Beeldvorming, haar totstandkoming — met speciale aandacht voor het aandeel van de DDR daarin - en haar effecten op beleid en standpuntbepaling, daar draait het bij Pekelder steeds om als hij de politieke, economische en kerkelijke betrekkingen reconstrueert. Het boek is weliswaar dik, maar verveelt nergens. Dat komt niet alleen door de grote diversiteit aan onderwerpen, de gedegen behandeling en grondige analyse ervan, maar vooral door de helderheid van de conclusies die logisch voortvloeien uit goed geconstrueerde betogen die op hun beurt gebaseerd zijn op voorbeeldig uitgevoerd onderzoek. Een prestatie van formaat!

\section{J. Bosmans}

P. Meel, ed., Op zoek naar Surinaamse normen. Nagelaten geschriften van Jan Voorhoeve (1950-1961) (Bronnen voor de studie van Suriname XX; Utrecht: CLACS, IBS, 1997, xii + 625 blz., f75,-, ISBN 903931883 2).

Heeft Nederland de buitenwereld ooit goed begrepen? Kan dat überhaupt"! De Nederlandse visie op het post-koloniale Indonesië en Suriname geeft weinig aanleiding tot optimisme. Zelfs met de Nederlandse Antillen lijkt Nederland vrijwel alleen nog te communiceren via het IMF. Wat een verschil met de Engelsen, die er na de dekolonisatiegolf in slaagden om vele exkoloniën op een vage manier - en vrijwel zonder kosten! - aan zich te binden door het Commonwealth.

Het lijkt vreemd om deze algemene vraag te verbinden met zoiets particularistisch als de uitgegeven correspondentie van een man, en dan nog niet eens van een staatsman, politicus of hoge militair, maar van een taalkundige en bijbelvertaler. Dat zou de veronderstelling rechtvaardigen dat deze bronnenpublicatie voornamelijk zou handelen over linguïstische en theologische problemen met waarschijnlijk een hoog kwezelgehalte.

Niets is minder waar. Jan Voorhoeve mocht dan als pas afgestudeerd neerlandicus naar Suriname zijn vertrokken, omdat hij geen academische betrekking in Nederland kon vinden, dat verhinderde hem niet om met bijna ontembare energie wetenschappelijk onderzoek te doen, les te geven, vertalingen te maken, het binnenland te bezoeken, een spellingshervorming van het Sra Tongo te propageren en het ontluikend nationalisme enig zelfbewustzijn in te blazen. 